\title{
MOK wt Allele
}

National Cancer Institute

\section{Source}

National Cancer Institute. MOK wt Allele. NCI Thesaurus. Code C51275.

Human RAGE wild-type allele is located within $14 q 32$ and is approximately $79 \mathrm{~kb}$ in length.

This allele, which encodes MAPK/MAK/MRK overlapping kinase protein, is involved in the induction of intracellular oxidative stress and a pro-inflammatory status in response to activation by advanced glycation end products. The RAGE gene is associated with a number of neurological disorders including Parkinson's disease, familial amyloidotic polyneuropathy, and vasculitic neuropathy. 